\title{
HIGH PERFORMANCE INVERTER FOR RENEWABLE ENERGY SYSTEMS
}

\author{
Sérgio Daher****, Jürgen Schmid* and Fernando Antunes** \\ * University of Kassel - Germany www.re.e-technik.uni-kassel.de Tel.: +49 / (561) - 804.6201 \\ ** Federal University of Ceará - Brazil www.dee.ufc.br Tel.: +55 / (85) - 3366.9580 \\ sdaher@secrel.com.br, jschmid@uni-kassel.de, fantunes@dee.ufc.br
}

\begin{abstract}
This paper makes an analysis of the current demand on inverters for stand-alone renewable energy applications, and shows that reliability, surge power capability and efficiency are the most important aspects to be considered. It is shown that multilevel topologies can be very suitable for these applications due to their inherent high efficiency and robustness. In addition, it is shown that an optimized design must be in agreement with the typical load profile for stand-alone applications. A prototype of $3 \mathrm{kVA}$ was implemented and it has proved itself to be robust. Peak efficiency of $96.0 \%$ was achieved: value that is higher than similar high performance inverters currently available in the market.
\end{abstract}

Keywords - Multilevel inverter, Renewable energy, Stand-alone system.

\section{INTRODUCTION}

Stand-alone Renewable Energy Systems - SARES are usually applicable when utility expansion cost is higher than a Renewable Energy System - RES investment. In fact, just few kilometers are enough to justify its use [1,2].

Although many SARES can be found in developed countries, such as houses in the European Alps, most demand is encountered in the developing countries. It is estimated that 2 billion of people are living without connection to the grid and this amount is increasing [3].

Despite of SARES size, location and explored RE resource, it is of common sense that it should be capable to supply alternating current (AC) electricity [4], thus providing compatibility with standard appliances that are cheap and widely available. On the other hand, most SARES include at least one DC voltage source that must be further converted into standard AC voltage source. Photovoltaic (PV) generators and most common energy storage devices are typical examples of DC voltage sources. According to these facts, it is evident that a device capable to convert DC voltage in AC voltage is a key element of most SARES.

The DC/AC converters, commonly referred as inverters, have experienced great evolution in the last decade due to its wide use in uninterruptible power supplies (UPS) and industry applications. However, they still to be critical components in most SARES and the development of high performance inverters is even today a challenge [5,6].

Inverters can be classified by their output waveform in four categories: square wave, modified square wave (also called quasi-square or modified sine wave), multilevel (or multi-step) and sine wave (usually synthesized

Manuscript submitted on 25/09/2006. Revised on 4/12/2006 and 31/1/2007. Accepted by recommendation of the Editor Richard M. Stephan. from a high frequency pulse width modulation - PWM). Figure 1 shows the waveforms for each category.

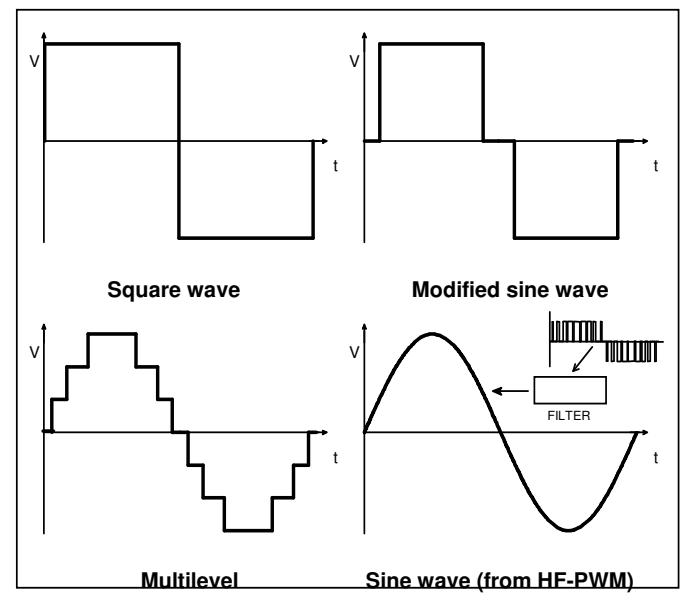

Fig. 1. Waveforms of different inverters technologies.

Although the square wave and the modified sine wave inverters can be acceptable in some applications, and are still available in the market, they are not recommend for new designs due to their poor quality waveform. Multilevel and sine wave inverters are considered the state-of-the-art technology and several topologies are used to implement them.

While for high power applications multilevel inverters are the best alternative (or, sometimes, the unique), for medium or low power applications a controversy takes place. Experts on high frequency converters point out the compactness and reduced cost that can be achieved by employing high frequency switching $[7,8]$. On the other hand, experts on low frequency converters claim that the very best efficiency and robustness belong to the topologies based on low frequency $[9,10]$.

In this work, a high-efficiency multilevel inverter is proposed as one of the best solutions to the current demand on reliable and efficient inverters for SARES.

\section{INVERTERS FOR SARES}

Parameters such as voltage and frequency regulation, total harmonic distortion and operation temperature, among others, can be considered as standard specifications that are matched by all high-quality inverters found in the market. On the other hand, besides cost, performance parameters and extra features have been used to specify an inverter according to each specific application.

Having in mind that SARES only make sense if they can be reliable and flexible, then all balance of system (BOS) components must accomplish with these characteristics. In 
this way, from the best of the author's knowledge, the most important characteristics of a RES inverter, in order or importance, are:

1) Reliability (most important);

2) Surge power capacity;

3) No-load consumption and efficiency.

\section{A1. Reliability}

Reliability is the probability that a device or system will perform its specified function in a given environment for a specified period of time. Traditionally, reliability of a system has been presented in terms of Mean-Time-Between-Failures (MTBF) and it is usually modeled by a Bathtub curve.

Although inverters have experienced great evolution in the last decade, even today they still have the bad reputation to be considered one of the most critical BOS of a RES [11]. In the particular case of PV RE systems, in which PV modules can present an expected lifetime of 25 years [12], inverters still to be a critical component.

In response to the current demand on RES quality and increasing market competition, reliability concerns have gained more attention. Nevertheless, while standard warranty up to 10 years are offered for grid inverters, manufactures are still timid to talk about expected lifetime of their stand-alone inverters. This fact shows how these components are critical and demand further improvements.

It is well know that voltage stress and temperature are factors that decrease lifetime of many components $[13,14]$. Considering this fact, it is expected that high efficiency (therefore lower working temperature) and stable (therefore less or more predictable voltage stress conditions) topologies, like the multilevel ones, can reach high degree of reliability.

\section{A2. Surge Power Capability}

Systems capable to start a refrigerator or a conventional water pump are undoubtedly more useful than systems that can supply only well-behaved devices, such as lights, radio and television. This is why surge capacity can be considered the second most important inverter feature.

In general, for the same cost-benefit relation, inverters based on low-frequency switching present higher surge power capacity when compared to similar products based on high frequency switching. In fact, current available HFPWM inverters usually present surge power around twice their rated power while inverters based on low frequency switching can easily present more than three times.

\section{A3. No-load Consumption and Efficiency}

Efficiency characteristic is directly related to the overall efficiency of a system, and also indirectly related to system reliability (higher efficiency usually implies in lower working temperature and stress) and durability (for example, lower losses can result in shorter battery discharge cycles). Therefore, inverters for SARES should present high efficiency, what can be achieved trough the use o multilevel topologies.

\section{B. Multilevel Inverters for SARES}

According to the explained, multilevel inverters offer all aimed features required by SARES applications. In fact, for small power systems $(<10 \mathrm{~kW})$, multilevel converters have been competing with high frequency PWM converters in applications where high efficiency is of major importance. Moreover, lower prices of power switches and new semiconductor technologies, as well as the current demand on high performance inverters required by RE systems, have extended the applications of multilevel inverters [15-18].

However, for the particular case of SARES, only few multilevel topologies can be applied due to the requirements of: 1) the topology must receive a single DC source input (from a battery bank); 2) the topology must be suitable to implement a high-resolution multilevel waveform (to avoid filter problems) and 3) the topology must support loads of unpredictable nature, such as half-wave loads. A detailed analysis of this problem is found in [19], where it is also found that the best topologies for SARES applications are the topologies shown in Figures 2 and 3.

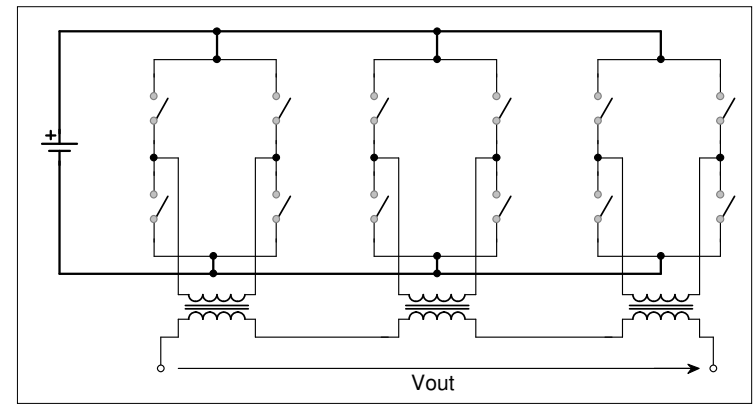

Fig. 2. Cascade H-bridge with several isolation transformers.

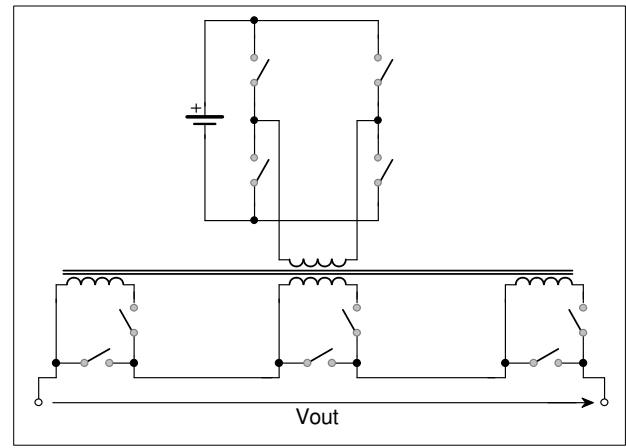

Fig. 3. Multi-winding-transformer topology (adopted topology).

The topology shown in Figure 2 has been used to implement successfully commercial products: earlier by TRACE Inc. and currently by XANTREX Inc. The topology shown in Figure 3 is not yet used commercially, but has great potential to future applications in RES. The latter is the topology adopted in this work (previously discussed in [20]).

\section{LOAD PROFILE AND INVERTER EFFICIENCY}

The first two main parameters of the load profile that affects inverter specification are the peak demand and surge power. While the peak demand is easily estimated by simply summing the nominal power of all consumer appliances (worst case), estimation of surge power is difficult because many appliances do not have precise information about their startup transient. Common examples are refrigerators and water pumps, which present startup current of several times of their rated value. 
As a fact, the average consumption of a rural property in Brazil has been estimated to be $45 \mathrm{kWh} /$ month with surge power of $5 \mathrm{~kW}$ [21]. Considering that all consumption occurs within 2 hours in a day (worst case supposition), then peak power demand is equal to $750 \mathrm{~W}$. In close, this application may require an inverter that should be capable to provide 750 $\mathrm{W}$ continuously and $5000 \mathrm{~W}$ of surge power, which will supply an average load demand of $63 \mathrm{~W}$. This example makes clear that high performance inverters must present high surge power capacity and low stand-by consumption.

Not less important, the energy distribution (as a function of the delivered power) is the third parameter that must be carefully observed. Figure 4 shows a typical example of such characteristic [22].

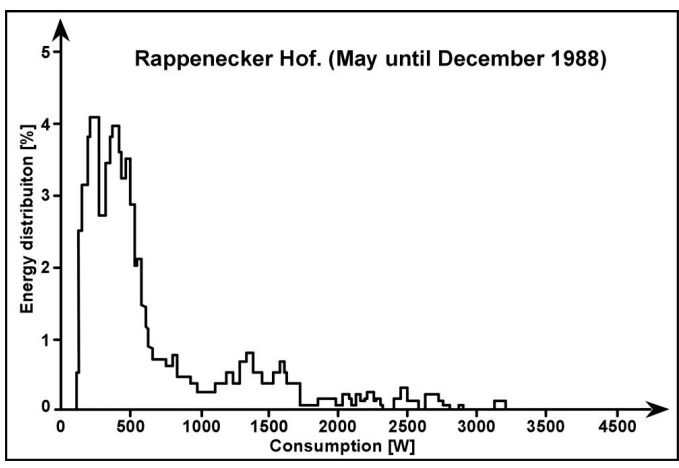

Fig. 4. Load profile of a typical stand-alone system (Rappenecker Hof [16])

In this load profile, $4 \%$ of the total energy demand is processed at the power of approximately $500 \mathrm{~W}$ while less than $1 \%$ is processed at about $2500 \mathrm{~W}$. This characteristic is fundamental to correctly estimate the overall inverter efficiency under practical load condition. In fact, a typical SARES inverter process most energy at a fraction of its nominal power; thus its efficiency characteristic must be optimized in the low load region, even if this implies in efficiency reduction at rated power.

Because of the relatively complex shape of the load profile, it is convenient to model the inverter efficiency characteristic by its no-load consumption $\left(\mathrm{P}_{\mathrm{nl}}\right)$ and conversion efficiency $\left(\eta_{c}\right)$ curve. Figure 5 shows how to calculate the equivalent conversion efficiency for a given conventional efficiency point.

As it can be seen in Figure 5, the extended model separates the no-load consumption from the conversion process. In consequence, for a given load profile, an inverter can be fully characterized by only two parameters: its noload consumption and its mean weighted conversion efficiency $\left(\eta_{\mathrm{cw}}\right)$.

The $\eta_{c w}$ is the mean value of the weighted $\eta c$ curve (weighted by Lp), and can be calculated by equation 1 .

$$
\eta_{\mathrm{cw}}=\frac{\int \eta_{c}\left(P_{o}\right) \cdot L_{p}\left(P_{o}\right) \cdot d P_{o}}{\int L_{p}\left(P_{o}\right) \cdot d P_{o}}
$$

where: $\mathrm{P}_{\mathrm{o}}$ is the inverter's delivered output power $(\mathrm{W})$; $\eta_{c}\left(P_{o}\right)$ is the conversion efficiency at $\mathrm{P}_{\mathrm{o}}(\%)$; $\mathrm{L}_{\mathrm{p}}\left(\mathrm{P}_{\mathrm{o}}\right)$ is the load profile weight at $\mathrm{P}_{\mathrm{o}}(\%)$.

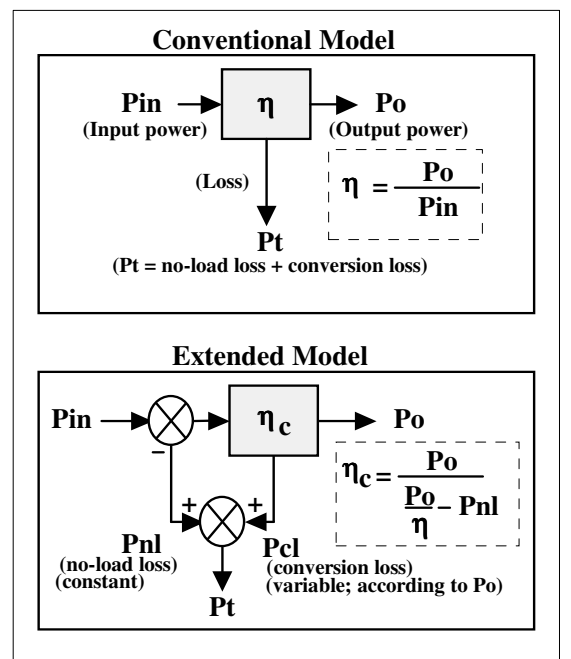

Fig. 5. Conversion between conventional model and extended model.

As an example, using an approximation of the load profile given in Figure 4, the calculated $\eta_{\mathrm{cw}}$ and respective efficiency curves (conventional and conversion) of a LF-based inverter (inverter-1) and HF-based inverter (inverter-2) are shown in Figure 6.

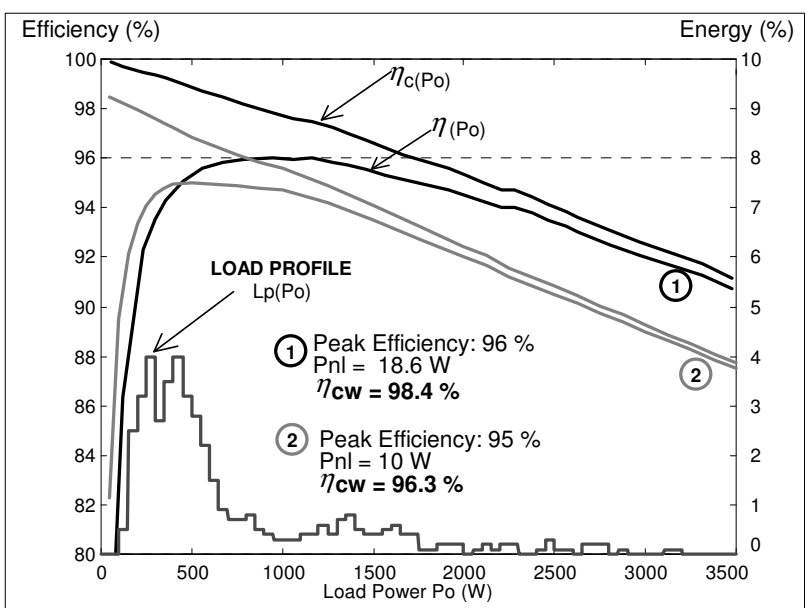

Fig. 6. Load profile and efficiency characteristic of two different converters.

From Figure 6, it is possible to conclude:

1) Although inverter-1 peak efficiency is only $1 \%$ higher than inverter-2, it is $2.1 \%$ more conversion-efficient for the given load profile.

2) The conversion efficiency versus power characteristic can be approximated by a straight line. This fact suggests that the efficiency characteristic of an inverter can be completely described by only 3 numbers: its noload consumption and the two coefficients of the line that better fits the $\eta c$ curve.

3) The conversion efficiency curve of inverter-1 approximately converges to the value of $100 \%$, while the inverter- 2 characteristic converges to a value between $98 \%$ and $99 \%$. This difference can be justified by the fact that inverter- 1 is based on lowfrequency switching and inverter-2 is based on highfrequency. 
As it can be seen, the efficiency model proposed in this work can simplify the specification of the efficiency characteristic (only 3 parameters are required, instead of a complete plot or table), while it can be directly applied to a load profile in order to calculate the overall system efficiency. In practice, many inverters manufactures only give information about no-load consumption and peak efficiency, what is not enough to precisely estimate the overall efficiency under practical load conditions.

In fact, while grid-interactive inverters are highly standardized, there is a lack of standards for stand-alone inverters. Perhaps, the proposed model could be useful for future specification of standards.

\section{THE PROPOSED INVERTER}

As shown in Figure 7, the proposed topology includes 3 main components: one H-bridge converter, one multiwinding transformer and one output-stage. The H-bridge converter receives voltage from a DC source, such as a battery bank, and generates a square waveform that is applied to the primary of the transformer. The transformer operates at line frequency and it has one primary and several isolated output coils of distinct voltages. The output-stage combines these partial voltages in order to produce the output voltage.

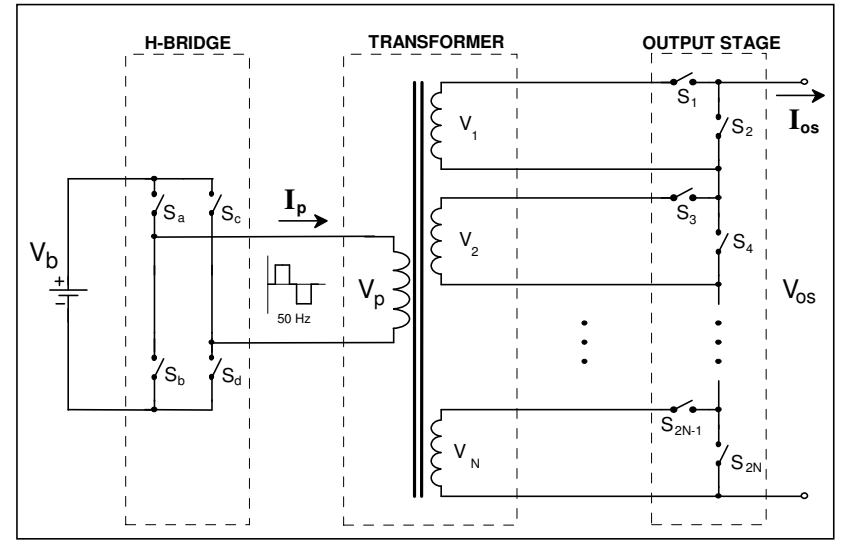

Fig. 7. The proposed topology.

The switches that compose the H-bridge stage must be capable to block voltages at one polarity only, and can be implemented by MOSFETs or IGBTs. On the other hand, all the switches that compose the output-stage must be capable to block AC voltage.

The number of levels that can be generated depends on the number of output-stage cells and also on their respective values. For a structure composed by $\mathrm{N}$ cells, the maximum number of levels (same polarity) that can be produced is $2^{\mathrm{N}}$ (including the zero). This condition is achieved if all outputcoil voltages are of distinct values and if the set of all possible combinations do not present repeated values.

\section{A. Operation Principle}

Without loss of generality, the operation principle of the adopted topology will be described using a structure with an output-stage composed by only two cells, as shown in Figure 8. The driver signals of all switches and the main voltage waveforms are presented in Figure 9.
The H-bridge switches operate at line frequency in order to produce a square voltage waveform $\left(\mathrm{V}_{\mathrm{p}}\right)$ that is applied to the primary of the transformer. In this example, it is used transformer relation-ratios of $1: 1$ and $1: 2$, so $V_{1}$ and $V_{2}$ are square waveforms with amplitudes of $V_{b}$ and $2 . V_{b}$, respectively.

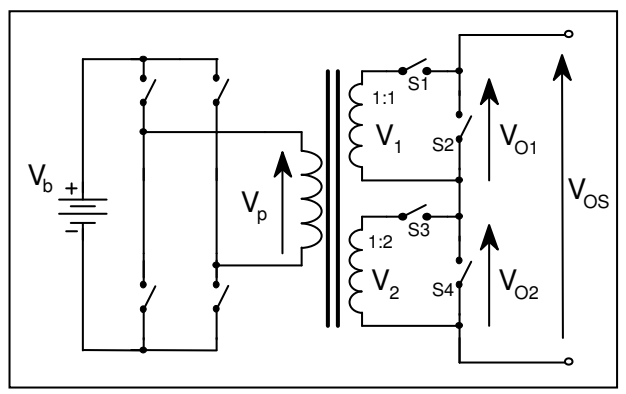

Fig. 8. Adopted topology: 2-cell structure.

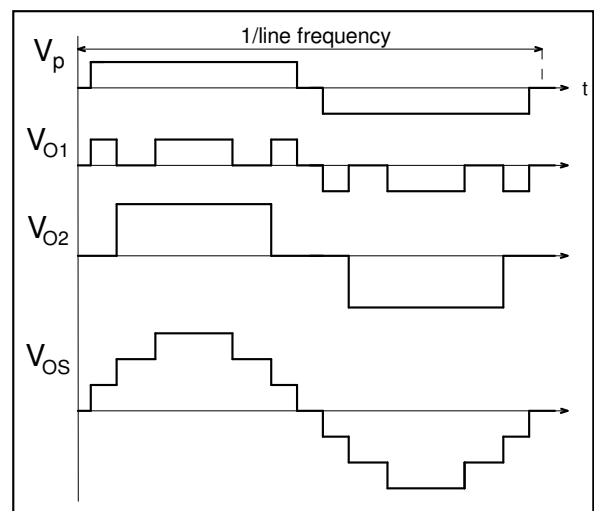

Fig. 9. Main waveforms for the 2-cell structure.

As it can be seen, each output coil is connected to two switches which operate complementarily $\left(S_{1}\right.$ and $S_{2}$ for the first output-cell and $S_{3}$ and $S_{4}$ for the second one). Thus each cell produces a partial voltage that can be equal to zero or to its respective coil voltage. As all cells are connected in series, the total output voltage is equal to the sum of all partial voltages and can assume distinct values depending on the state of the H-bridge and output-stage switches.

Different from other topologies, this topology can only sum partial voltages. This fact limits the maximum number of steps in $2^{\mathrm{N}-1}$ (per quarter cycle). Nevertheless, this kind of operation does not include "forced reverse-power-flow" and high efficiency can be achieved.

\section{B. Prototype Specification}

The adopted design specifications are listed in Table I.

TABLE I

Design specifications

\begin{tabular}{|c|c|}
\hline Rated power & $3000 \mathrm{VA}$ \\
\hline Rated input voltage & $48 \mathrm{~V}$ \\
\hline Output voltage & $230 \mathrm{~V}_{\mathrm{CA}} / 50 \mathrm{~Hz}$ \\
\hline Voltage regulation & $+5 \%,-10 \%$ \\
\hline THD & $<5 \%$, \\
\hline
\end{tabular}

Although these specifications were arbitrary defined, they are based on the following facts: 
- A $3 \mathrm{kVA}$ inverter fits to several SARES applications and it is a reasonable value to validate the proposed topology. Also, several commercial inverters are rated to $3 \mathrm{kVA}$, and posterior comparison between the proposed inverter and similar products could be done;

- An input voltage of $48 \mathrm{~V}$ is suitable for a $3 \mathrm{kVA}$ power rating (regarding current level). It can also be considered a standard value commonly found in SARES applications;

- Output voltage of $230 \mathrm{VAC} / 50 \mathrm{~Hz}$ is the standard utility voltage in Germany, where the inverter had to be implemented and tested;

- The adopted values of voltage regulation and THD attend current utility standard limits, according to the European Standard EN 50160 and IEEE Std 519-1992, for example.

\section{Simulation}

According to the prototype specification presented in topic $\mathrm{B}$, the main structure of a 5-stage inverter was defined and its simplified schematic circuit is shown in Figure 10.

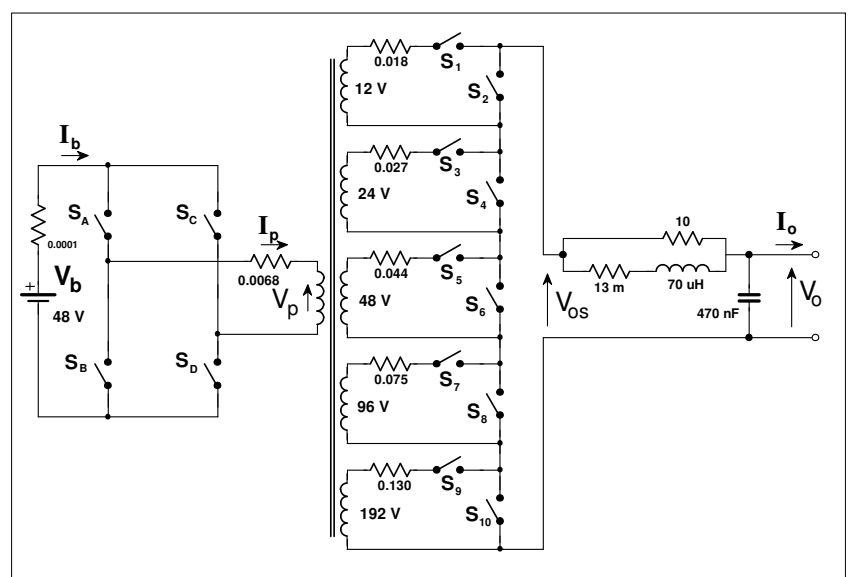

Fig. 10. Simplified schematic circuit of the proposed inverter.

Figure 11 shows the simulation result for the output-stage voltage $\left(\mathrm{V}_{\mathrm{os}}\right)$ for a resistive load of $1 \mathrm{~kW}$ (without output filter). Some spikes can be observed, which are due to the dead-time intervals between the switch signals of a same cell.

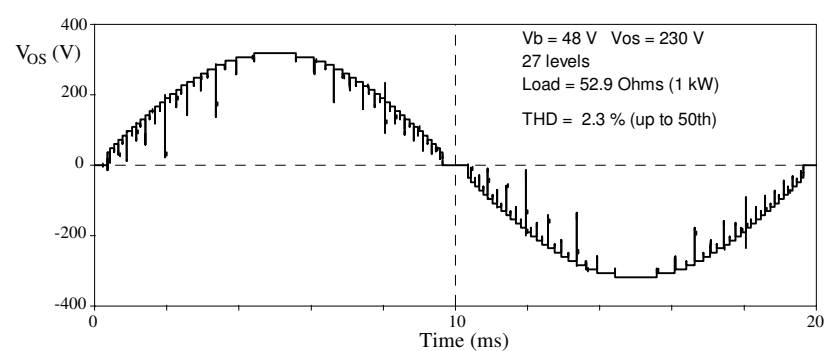

Fig. 11. Simulation result: output-stage voltage, without filter.

The output voltage (including the output filter) is shown in Figure 12, where it is possible to observe the importance of the output filter, which almost eliminates the undesirable voltage spikes.

Figure 13 shows the voltage and current waveforms for inverter operation under pure inductive load. As it can be seen, the output voltage is still comported and bi-directional operation is evident in both AC and DC sides. The current spikes presented in the battery current waveform are due to the quick charge of the dissipative snubbers implemented in all switches.

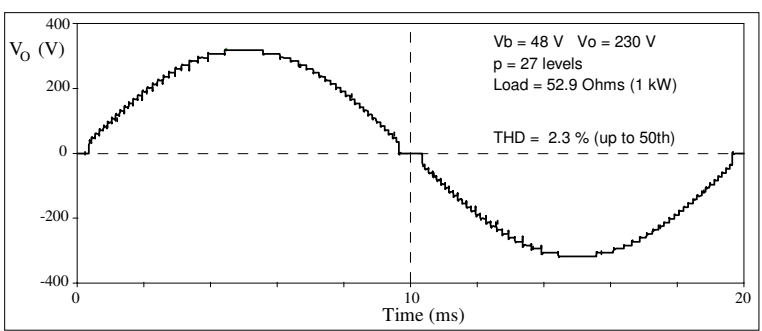

Fig. 12. Simulation result: output-stage voltage, with filter.

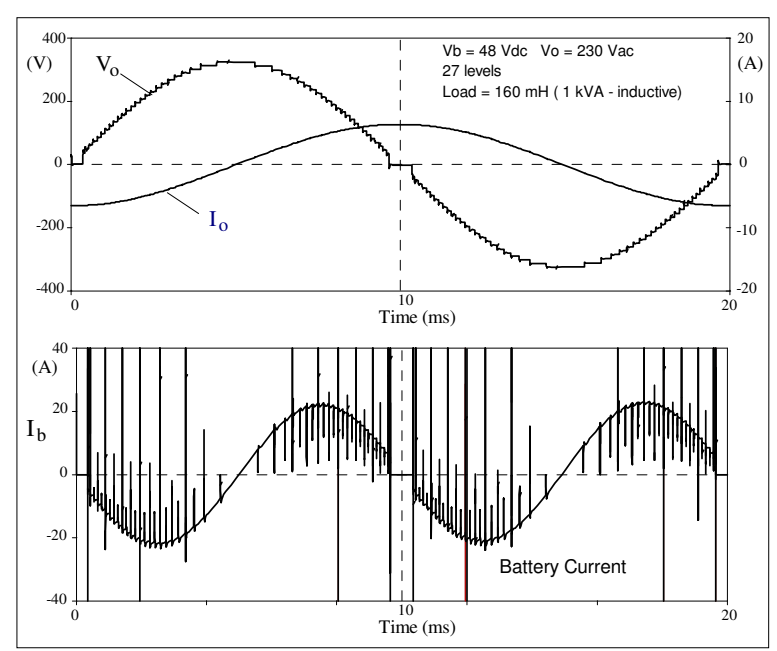

Fig. 13. Simulation result: Operation with pure inductive load.

\section{PROTOTYPE IMPLEMENTATION}

In order to compare the prototype with commercial inverters, special care was taken while designing the prototype. As a result, the experimental set-up was not designed to work only in a laboratory environment, but it is a full-functional inverter (unclosed version). Figure 14 shows a block diagram of the complete system.

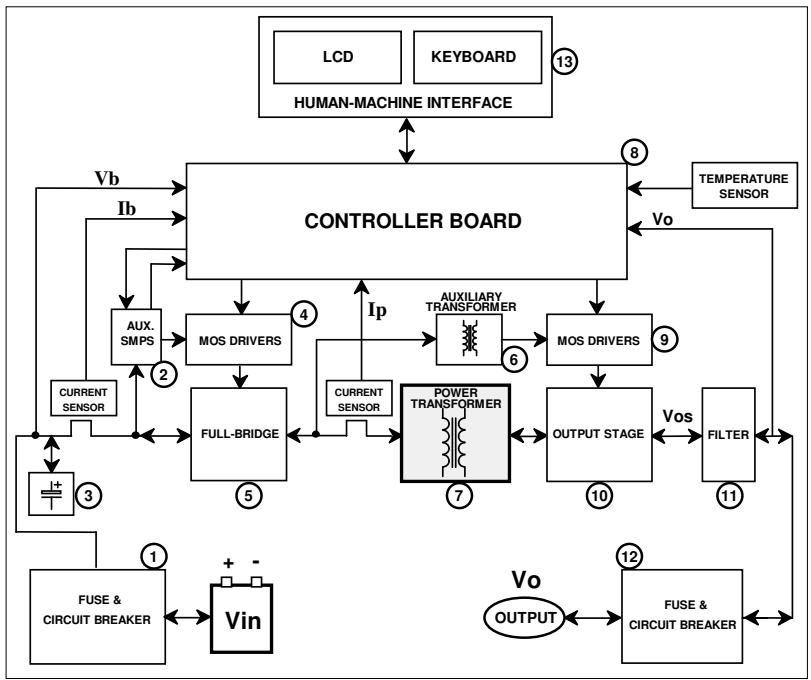

Fig. 14. Block diagram, showing all components. 
Figure 15 shows a picture of the prototype, where it can be identified all components previously labeled in Figure 14.

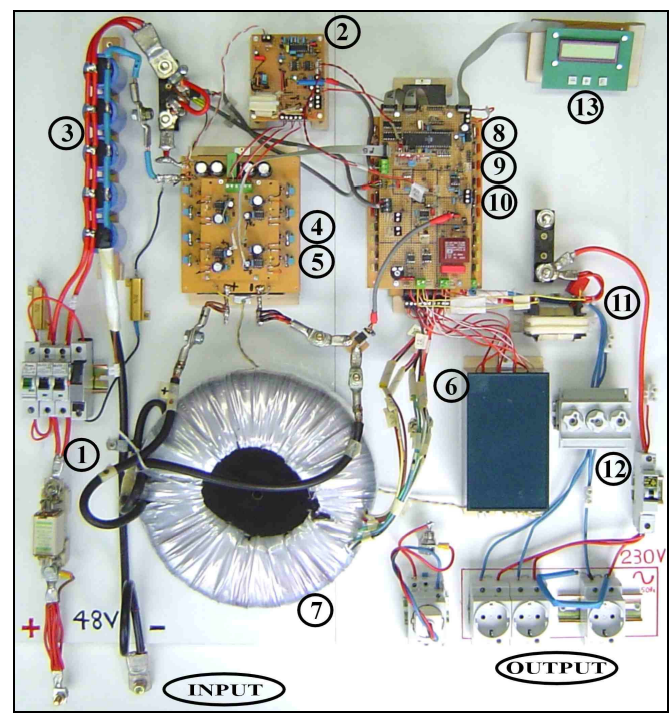

Fig. 15. Prototype top view.

\section{A. Bi-directional Switch Configuration}

As explained, all output-stage switches must be capable to operate with $\mathrm{AC}$ voltage and current. In practice, this type of switch is not yet available as a single component. However, using MOSFETs, it can be implemented by association of some components, as shown in Figure 16.

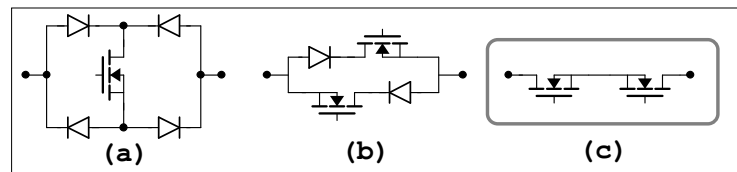

Fig. 16. Bi-directional switch implementations using MOSFETs.

Configuration (c) was chosen because it can provide lower losses when compared to (a) and (b), due to the low resistance of modern MOSFETS and also due its bidirectional channel conduction capability.

\section{B. Specification of switches and snubbers}

Table II shows the switches and snubbers specifications used in the implemented prototype.

TABLE II

Component data for main power switches and snubbers

\begin{tabular}{|c|c|c|c|c|c|c|c|c|}
\hline \multirow[t]{2}{*}{ Stage } & \multirow[t]{2}{*}{ (V) } & \multicolumn{4}{|c|}{ MOSFET DATA } & \multirow{2}{*}{$\begin{array}{c}\mathrm{Z}_{\mathrm{n}} \\
(\mathrm{V})\end{array}$} & \multirow{2}{*}{$\begin{array}{l}\mathrm{R}_{\mathrm{n}} \\
(\Omega)\end{array}$} & \multirow{2}{*}{$\begin{array}{c}\mathrm{C}_{\mathrm{n}} \\
(\mathrm{nF})\end{array}$} \\
\hline & & Reference & $\begin{array}{l}\mathrm{V}_{\mathrm{ds}} \\
(\mathrm{V})\end{array}$ & $\begin{array}{c}\mathrm{I}_{\mathrm{d}} \\
{[\mathrm{A}]}\end{array}$ & $\begin{array}{c}\mathrm{R}_{\mathrm{ds}} \\
(\mathrm{m} \Omega)\end{array}$ & & & \\
\hline FB & 48 & $\begin{array}{c}2 \mathrm{x} \\
\text { IRFP2907 }\end{array}$ & 75 & $\begin{array}{c}2 \mathrm{x} \\
209\end{array}$ & $4.5 / 2$ & 66 & 330 & 470 \\
\hline Cell 1 & 12 & IRF3205 & 55 & 110 & 8 & 22 & 120 & 47 \\
\hline Cell 2 & 24 & IRF3205 & 55 & 110 & 8 & 33 & 330 & 47 \\
\hline Cell 3 & 48 & IRF2807 & 75 & 82 & 13 & 66 & 330 & 47 \\
\hline Cell 4 & 96 & IRFP260N & 200 & 50 & 40 & 130 & 470 & 47 \\
\hline Cell 5 & 192 & APT30M40 & 300 & 76 & 40 & 250 & 470 & 47 \\
\hline
\end{tabular}

\section{Power Transformer (3 kVA, toroidal)}

The use of toroidal shape allowed the transformer to present low no-load losses (13.0 W @ 48 Vrms - squared wave), reduced weight $(32 \mathrm{~kg}$ ) and size (diameter of $32 \mathrm{~cm}$, height of $13 \mathrm{~cm}$ ). This transformer is a customer type that was designed (standard rules, using $\mathrm{Si}-\mathrm{Fe}$ GO laminations of grade DIN VM89-27) and manufactured by a specialized company (using automatic winding machine).

\section{EXPERIMENTAL RESULTS}

The output voltage waveform is shown in Figure 17.

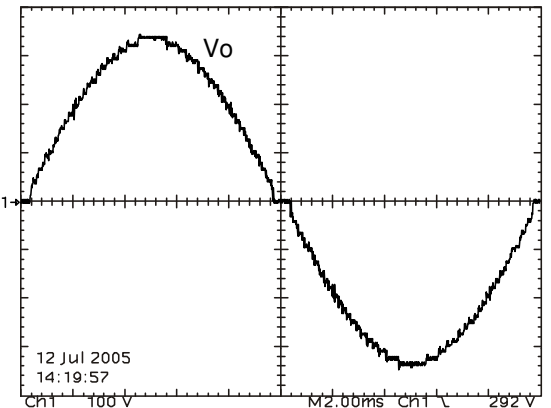

Fig. 17. Output voltage at no-load condition.

As it can be seen, the experimental output waveform approximates a perfect sinusoidal shape, apart from the distortions near zero crossing. These distortions correspond to a fixed time of $700 \mu \mathrm{s}$, where the output voltage is forced to be zero, and it is used to control transformer-unbalancing.

Operation of a nearly pure inductive load is presented in Figure 18. As showed in Figure 18.a, the load current is delayed by almost 90 degrees. Bi-directional power flow handling capability can be verified in Figure 18.b, where the battery current assumes positive and negative values.

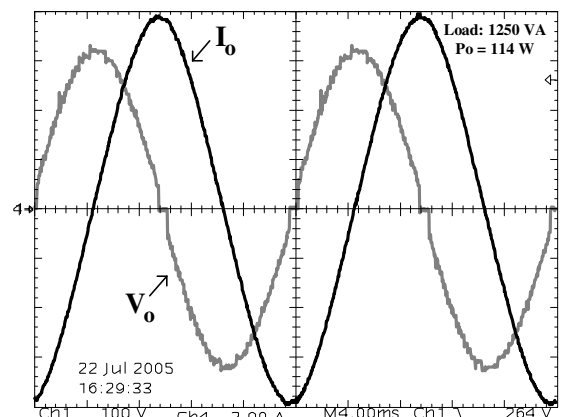

(a)

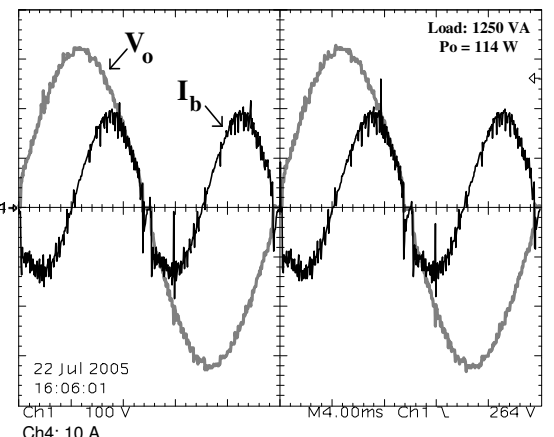

(b)

Fig. 18. Waveforms for operation under inductive load: a. Output voltage and current; b. Output voltage and battery current.

A refrigerator is commonly desired in residential applications and it is known to be a problem in many small stand-alone systems due to its high startup current. Figure 19 shows the waveforms acquired at the startup of a refrigerator. 


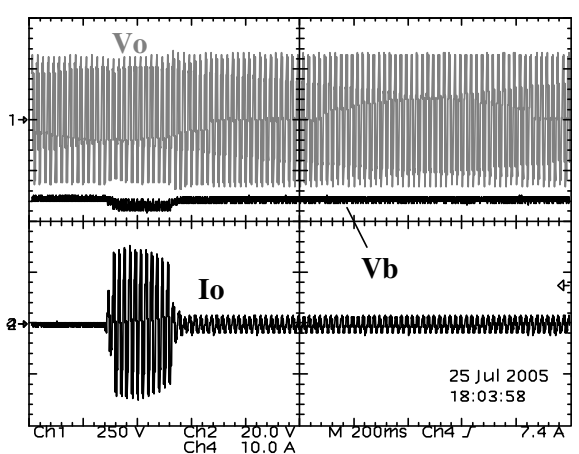

Fig. 19. Waveforms for a refrigerator startup.

At steady state operation, the measured current was $1.0 \mathrm{~A}$ (RMS), while according to Figure 19, the current at startup is approximately 10.6 A (RMS). Thus, even this small refrigerator may require $2.4 \mathrm{kVA}$ at startup.

The efficiency versus output power characteristic curves of the implemented prototype is shown in Figure 20. Peak efficiency of $96.0 \%$ at an output power of $945 \mathrm{~W}$ was measured for an input voltage of $48 \mathrm{~V}$.

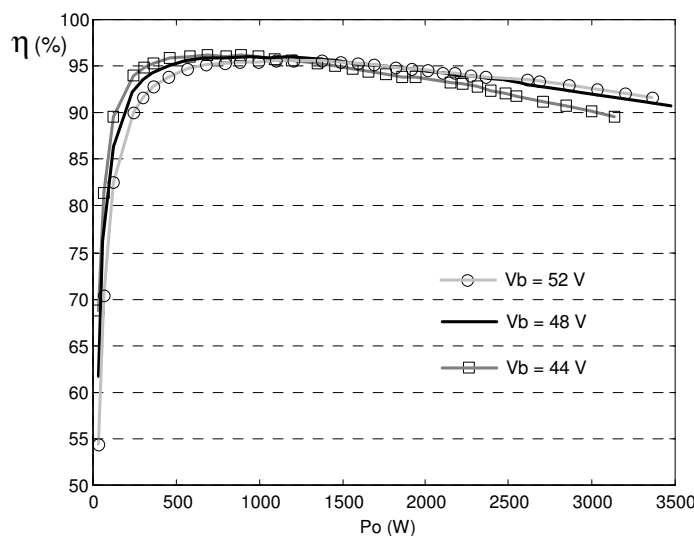

Fig. 20. Efficiency x output power characteristic (resistive load)

In addition, the proposed prototype was also capable to successfully operate non-linear loads, such as microcomputers and half-wave loads (up to $1500 \mathrm{~W}$ ). Thanks to its bi-directional characteristic and also to the implemented control to prevent transformer unbalancing, no problems were observed while operating these loads.

A summary of the main characteristics of the prototype and some commercial inverters is shown in table III.

TABLE III

Comparison of inverters

\begin{tabular}{|c|l|c|c|c|}
\hline No. & \multicolumn{1}{|c|}{ Inverter } & Power $(\mathrm{VA})$ & $\eta_{\mathrm{pk}}(\%)$ & No-Load $(\mathrm{W})$ \\
\hline 1 & Implemented prototype & 3000 & 96.0 & 18.6 \\
\hline 2 & Phoenix 48/3000/35 & 3000 & 95.0 & 10.0 \\
\hline 3 & Dakar 48/3000/50 & 3000 & 90.0 & 4.8 \\
\hline 4 & SMA Sunny Island 3324 & 3300 & 94.5 & 22 \\
\hline 5 & Trace SW3048 & 3300 & 95.0 & 16.0 \\
\hline 6 & Xantrex SW2548 & 2500 & 95.0 & $<20$ \\
\hline
\end{tabular}

As it can be seen in table III, the implemented prototype presents the best peak efficiency $(96.0 \%)$. In comparison with an inverter of $95.0 \%$ (at the same output power), the apparently small difference of $1 \%$ corresponds to loss reduction of $20 \%$. At the end, this saving can imply in lower working temperature and consequently longer lifetime.
Regarding no-load consumption, the proposed inverter present a reasonable value if it is considered that it competes only with inverters 2 and 5 . In fact, inverter 3 can not be used as reference because their poor efficiency characteristic, and inverters 6 and 4 probably present higher no-load consumption allied to worst peak efficiency.

Considering the typical load profile presented in Figure 4, conclusive investigation can be done by observing Figure 21 .

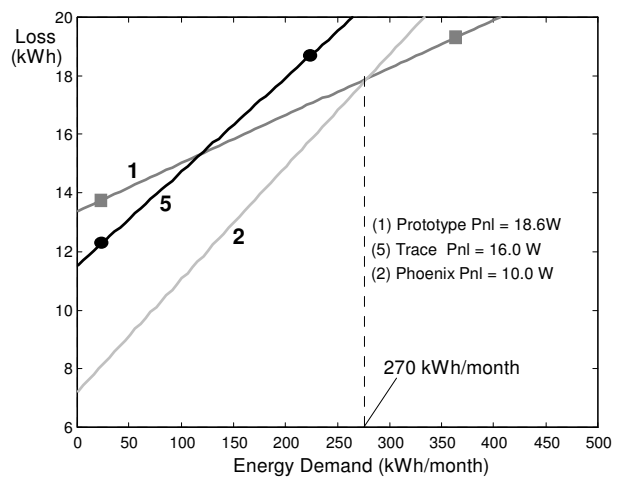

Fig. 21. Monthly energy loss versus processed energy.

As it can be seen in Figure 21, inverter-2 present lower loss for any energy demand of up to approximately 270 $\mathrm{kWh} /$ month (average: $375 \mathrm{~W}$ ), and above this value the proposed inverter is more efficient. In comparison with inverter-5, the proposed inverter present better efficiency for any energy demand above approximately $120 \mathrm{kWh} /$ month.

\section{CONCLUSIONS}

This work shows that SARES demand for inverters with improved characteristics of reliability, capability to start heavy loads and efficiency, and all these benefits can be achieved through the use of multilevel topologies, such as the adopted multi-winding-transformer topology.

According to the typical load profile of most SARES, the battery inverter should be optimized to the operation at light load conditions, once these systems operates most of the time with a fraction of their rated power. The proposed efficiency model is an interesting approaching that can be applied to this optimization process analysis and can also be useful to a better specification of the inverters for these applications.

The implemented prototype presented peak efficiency of $96.0 \%$ and could be considered a top-efficiency inverter for the power range of about $3 \mathrm{kVA}$. Considering a typical load profile and in comparison with similar high-quality commercial inverters, it was found that the implemented prototype can achieve the best efficiency performance for any load demand greater than $270 \mathrm{kWh} /$ month.

\section{ACKNOWLEDGEMENTS}

The Authors wish to thank UNIKASSEL, ISET, DeMoTec, GPEC and CAPES for supporting this research.

\section{REFERENCES}

[1] J. A. Marini, L. A. Rossi, "Sistematização do Dimensionamento Téc. e Econô. de Sist. Fotovoltaicos Isolados por Meio de Prog. Computacional", Eng. Agríc., Jaboticabal, v.25, n.1, p.67-75, jan./apr. 2005. 
[2] F. Salvesen and K. AS, "National Survey Report of PV Power Applications in Norway 2003," International Energy Agency, Co-operative Program on PV Power Systems Task 1, Exchange and dissemination of inf. on PV power systems, Hoffsveien - Oslo, June 2004.

[3] P. Schweizer-Ries et. al, "Successful User Schemes for Photovoltaic-Stand Alone Systems Solar Energy for Rural Electrification - Lessons learned", prepared by Fraunhofer-Institut für Solar Energiesysteme - ISE and others, Freiburg - Germany, May 2000.

[4] W. Durisch, S. Leutenegger and D. Tille, "Comparison of Small Inverters for Grid-Independent Photovoltaic Syst.," Renewable Energy, No. 15, pp. 585-589, 1998.

[5] A. B. Maish et. al (Sandia National Laboratories), "Photovoltaic System Reliability," in Proc. of the 26th IEEE Photovoltaic Specialists Conference, Anaheim California, October 1997.

[6] A. Pregelj, M. Begovic, A. Rohatgi, "Impact of Inverter Config. on PV Syst. Reliability and Energy Production," in Proc. of the 29th IEEE Photovoltaic Specialists Conf., New Orleans, Louisiana, May 2002.

[7] E. Hiraki et al, "Zero-Voltage and Zero-Current SoftSwitching PWM Inverter with a Single ARDCL Cell," in Proc. of the IEEE 36th Annual Power Electr. Spec. Conf. - PESC05, Recife-Brazil, pp. 798-803, June 2005.

[8] P.T. Krein, R.S. Balog and X. Geng, "High-frequency Link Inverter for Fuel Cells Based on Multiple-Carrier PWM," IEEE Transactions on Power Electronics, vol. 19, no. 5, September 2004.

[9] K. A. Corzine and J. R. Baker, "Multilevel VoltageSource Duty-Cycle Modulation: Analysis and Implementation," IEEE Transactions on Industrial Electronics, vol. 49, no. 5, pp. 1009-1016, Oct. 2002.

[10] F. Z. Peng, "A Generalized Multilevel Inverter Topology with Self Voltage Balancing," IEEE Transactions on Industry Applications, vol. 37, no. 2, pp. 611-618, March-April 2001.

[11] W. Bower, "Inverters - Critical Photovoltaic Balanceof-system Components: Status, Issues, and New Millennium Opportunities," Progress in Photovoltaics Applications Res. Appl. 8, pp. 113-126, 2000.

[12] M. A. Green, "Silicon Photovoltaic Modules: A Brief History of the First 50 Years", Progress in Photovoltaic Research and Applications, published online in Wiley InterScience (www.interscience.wiley.com), DOI: 10.1002/pip.612, John Wiley \& Sons, Ltd, 2005.

[13] Hitachi Ltd., "Reliability Handbook," ADE-410-002, Rev. 1.0, Japan, January 2002.

[14] B. W. Williams, "Power electronics: devices, drivers, applic. and passive components," 2nd Edition, McGraw-Hill, 1992.

[15] H. Ertl, J. W. Kolar and F. C. Zach, “A Novel Multicell DC-AC Converter for Applications in Renewable Energy Systems," IEEE Transactions on Industrial Electronics, vol. 49, no. 5, October 2002.

[16] B. Ozpineci, L.M. Tolbert and Z. Du, "Optimum Fuel Cell Utilization with Multilevel Inverters," in Proc. of the IEEE 35th Annual Power Electronics Specialists Conference - PESC04, Aachen, pp. 4798-4802, 2004.
[17] M. Calais, V. G. Agelidis and M Meinhardt, "Multilevel Converters for Single-Phase Grid Connected Photovoltaic Systems: An Overview," Solar Energy, Vol. 66, no. 5, pp. 325-335, 1999.

[18] L.M Tolbert and F. Z. Peng, "Multilevel converters as a utility interface for renewable energy systems," in Proc. of the IEEE Power Engineering Society Summer Meeting, vol. 2, pp. 1271-1274, 2000.

[19] S. Daher, "Analysis, Design and Implementation of a High Efficiency Multilevel Converter for Renewable Energy Systems", Doctor Thesis - Universität Kassel Germany, June 2006.

[20] S. Daher, J. Schmid and F.L.M. Antunes, "Design and Implementation of an Asymmetrical Multilevel Inverter for Renewable Energy Systems", in Proc. of the COBEP 2005, pp. 199-204, Recife, 2005.

[21] L. A. ROSSI, "Modelo avançado para planejamento de sistemas energéticos integrados usando recursos renováveis," Doctor Thesis - Escola Politécnica, Universidade de São Paulo, São Paulo - Brazil, 1995.

[22] J. Müller, "Untersuchung und Optimierung von StuffenInvertern für Photovoltaik-Anlagen", Doctor Thesis, Fernuniversität / Fraunhofer-Institut für Solare Energiesystem, Freiburg - Germany, 1994.

\section{BIOGRAPHIES}

Sérgio Daher, was born in Fortaleza, Brazil, in 1971. Received the B.Sc. degree in Electrical Engineering from Universidade Federal da Paraíba - Brazil, M.S. degree in Electrical Engineering from Universidade Federal do Ceará UFC- Brazil, and Dr. -Ing. in Electrical Engineering from Universität Kassel - Germany (2006). Currently, he is a researcher (CNPq / CT-Energ) at UFC.

Jürgen Schmid, was born in Isingen, Germany, in 1944. From 1966 until 1972 he studied Aerospace Technology at Stuttgart University and graduated (PhD) in 1976 at the Dep. of Engineering at Karlsruhe University. From 1972 until 1979 he worked as a scientist at the Institute for Nuclear Process Engineering in Karlsruhe before becoming Project Manager until 1980 at Dornier System Ltd. Prof. Schmid was Head of Dep. of System Engineering at the Fraunhofer Institute for Solar Energy Systems (ISE) in Freiburg from 1981 to 1993. From May 1992 until Dec. 1995 he was Professor at Karlsruhe University. Since 1995, he is Professor/Head of the Dep. for Efficient Energy Conversion at the University of Kassel and simultaneously since 1998 Chairman of the Executive Board at the Institut für Solare Energieversorgungstechnik (ISET).

Fernando Luiz Marcelo Antunes, was born in Cascavel, CE Brazil, in 1956. Received the B.Sc. degree in Electrical Engineering from Federal University of Ceará-Brazil, B.Sc. degree in Business and Administration from the State University of Ceara-Brazil, MSc degree from the University of São Paulo (Brazil), and $\mathrm{PhD}$ degree from Loughborough University of Technology - United Kingdom (UK). He is a lecturer at Federal University of Ceará (Brazil). He coordinates the Energy Processing and Control Group of the DEE of the UFC, where research projects are carried out with financial support of public and private partners. He is member of The SOBRAEP, SBA and IEEE. 